\title{
Fisher women with the decision making in household task, their children education and marriage
}

\author{
HEMANT JADHAV ${ }^{1}$ AND GIRISH DESHMUKH* \\ Junagadh Agriculture University, JUNAGADH (GUJARAT) INDIA \\ (Email : 251girish@gmail.com)
}

\begin{abstract}
Fisheries as an occupation includes capture, culture, handling and processing of fish, marketing, distribution, accounting and management. Women play a key role in the development of fisheries sector in addition to their role as sole household managers in most fisher families. Although the involvement of women is limited in capture fisheries, their supportive role in active fishing has increased manifold with the advent of mechanization and enhancement of multi-day fishing in marine fisheries. Matasya-Mahilavadi (fisherwomen's Forum), at South Chellanam, a fishing village in cochin, is an example of how rural women can be motivated to participate in planning and implementing their own development options. Under Indian social system, decision making is said to be a men's affair, however, many a times women are consulted by men before making any important decision. Many a times farm women are also required to take certain decision independently. It was therefore, felt necessary to determine the participation of fisher women in making decision about household task, their children education and marriage.
\end{abstract}

Key Words : Fisherwomen, Home expenditure, Marriage, Education, Decision

View Point Article : Jadhav, Hemant and Deshmukh, Girish (2014). Fisher women with the decision making in household task, their children education and marriage. Internat. J. Home. Sci. Extn. \& Comm. Mgmt., 1 (2): 97-101.

Article History : Received : 01.05.2014; Revised : 28.05.2014; Accepted : 06.06.2014

* Author for correspondence

${ }^{1}$ Agritech School, Mahatma Phule Krushi Vidyapeeth, Malegao camp, NASHIK (M.S.) INDIA 